\title{
Biomitografia zakwestionowana. Sendlerowa. W ukryciu Anny Bikont jako performans tekstualny
}

\begin{abstract}
Paulina, Biomitografia zakwestionowana. Sendlerowa. W ukryciu Anny Bikont jako performans tekstualny [Contested biomythography. Sendlerowa. W ukryciu by Anna Bikont as a textual performance]. „Przestrzenie Teorii” 34. Poznań 2020, Adam Mickiewicz University Press, pp. 147-164. ISSN 1644-6763. DOI 10.14746/pt.2020.34.6.
\end{abstract}

The article is a performative interpretation of Sendlerowa. W ukryciu, a biography of Irena Sendlerowa by Anna Bikont. The author of the article presents the biography as a textual performance, whose aim is to contest the well-known image of Irena Sendlerowa (described within the category of biomythography introduced by Michael Benton). The author analyses how Anna Bikont distances herself from the biomythography and reintroduces the parts of Sendlerowa's biography that had been omitted for years through being incompatible with the role of a national hero. She also evaluates the extent to which biography can serve as a critical tool with respect to Polish historical policy.

KEYWORDS: textual performance, biomythography, historical policy

W momencie publikacji książki Anny Bikont Sendlerowa. W ukryciu Irena Sendlerowa już od wielu lat była osoba powszechnie znaną. Po ogłoszeniu przez sejm roku jej imienia ${ }^{1}$, ukazało się m.in. kilka książek dla dzieci², a także polskie tłumaczenie komiksu Davida Evrarda Irena według scenariusza Jean-Davida Morvana i Séverine’a Tréfouëla ${ }^{3}$. W tym czasie miała również miejsce premiera kolejnego, rozszerzonego wydania biografii autorstwa Anny Mieszkowskiej pod tytułem Historia Ireny Sendlerowej ${ }^{4}$. Liczne są także przykłady upamiętnienia tej postaci w przestrzeni publicz-

${ }^{1}$ Rok 2018 został ogłoszony Rokiem Ireny Sendlerowej przez sejm 8 czerwca 2017 roku. Por. <http://roksendlerowej.pl/uchwala/> [dostęp: 21.06.2019].

${ }^{2}$ Por. A. Czerwińska-Rydel, Listy w butelce. Opowieść o Irenie Sendlerowej, Łódź 2018; E. Nowak, Kto uratowat jedno życie. Historia Ireny Sendlerowej, Warszawa 2018; B. Ostrowicka, Irena Sendlerowa. Magiczny koralik, Warszawa 2018.

${ }^{3}$ Por. Irena. $1 / 3$ - Getto, scenariusz: J.-D. Morvan i S. Tréfouël, rysunek: D. Evrard, przeł. M. Fangrat, Warszawa 2017; oraz tych samych autorów: Irena. 2/3 - Sprawiedliwi, Warszawa 2017; Irena. 3/3 - Warszawa, Warszawa 2018.

${ }^{4}$ A. Mieszkowska, Historia Ireny Sendlerowej, Warszawa 2018. Książka ta jest rozszerzoną wersją pierwszej biografii Ireny Sendlerowej, która ukazała się w 2004 roku pod tytułem Matka dzieci Holocaustu. Historia Ireny Sendlerowej. 
nej: jej imię nadano w 2018 roku kilku szkołom, a w Rzeszowie odsłonięto kolejny mural z jej podobizną ${ }^{5}$.

Od kilku lat można zauważyć wykształcenie się kanonicznego wizerunku Ireny Sendlerowej. Do jego upowszechnienia najbardziej przyczynił się plakat reklamujący film Dzieci Ireny Sendlerowej ${ }^{6}$, na którym widzimy Annę Paquin, odtwórczynię głównej roli, w czepku pielęgniarskim ${ }^{7}$. W efekcie wielokrotnego powielania tego wizerunku pojawiła się tendencja do przedstawiania Sendlerowej jako pielęgniarki, widoczna zwłaszcza w szacie graficznej biografii, m.in. najnowszego wydania książki Anny Mieszkowskiej oraz dwóch publikacji dla dzieci, autorstwa Ewy Nowak i Beaty Ostrowickiej; tym tropem poszedł też autor projektu rzeszowskiego muralu. Osoby decydujące się na przedstawienie Sendlerowej w stroju pielęgniarki bazują najczęściej na tej samej fotografii, z grudnia 1944 roku. Praca ta (a wcześniej rola sanitariuszki w powstaniu warszawskim) była zaledwie krótkim epizodem w jej biografii, natomiast przed powstaniem i po zakończeniu wojny Sendlerowa była pracownica opieki społecznej.

Znaczenie praktyki przedstawiania jej jako pielęgniarki staje się czytelne, kiedy uznamy je za element strategii budowania wizerunku, zapowiedź i streszczenie narracji, którą znajdujemy w tekstach. Wobec braku charakterystycznego wizualnego elementu związanego z opieką społeczna, autorzy okładek zdecydowali się posłużyć epizodem z biografii Sendlerowej. Z „matką dzieci Holocaustu” kojarzony jest także zestaw cech charakteru, takich jak wrażliwość, życzliwość czy opanowanie ${ }^{8}$. Sendlerowa była na tyle wrażliwa na cierpienie mieszkańców getta, że postanowiła ratować żydowskie dzieci, a jednocześnie na tyle opanowana, by robić to skutecznie. To, że wymienione cechy równie łatwo przypisać pielęgniarce, co pracownicy opieki społecznej, pozwala przypuszczać, że wybór tej pierwszej opcji był podyktowany głównie względami wizualnymi.

Drugim istotnym elementem dominującego wizerunku Ireny Sendlerowej jest rola polskiej bohaterki narodowej ${ }^{9}$. W publikacjach dla dzieci często pojawiają się informacje o przyznanych jej odznaczeniach, czasem

${ }^{5}$ Por. <http://roksendlerowej.pl/badzcie-jak-irena-sendler-mural-jej-imienia-w-rzeszowie-odsloniety/> [dostęp: 5.06.2019]. Murale przedstawiające Irenę Sendlerową znajdują się także np. w Warszawie, Cieszynie czy Świdnicy.

${ }^{6}$ Tytuł oryginalny: The Courageous Heart of Irena Sendler, reż. John Kent Harrison, 2009.

${ }^{7}$ Plakat został wykorzystany m.in. na okładce wznowionej biografii Anny Mieszkowskiej, która dwukrotnie ukazała się pod tytułem Dzieci Ireny Sendlerowej (2007, 2009).

${ }^{8}$ Takie skojarzenia budzą zwłaszcza okładki książek dla dzieci, na których Sendlerowa przedstawiona została z dwójką lub trójką dzieci, które tuli do siebie lub trzyma za rękę.

${ }_{9}^{9}$ Jedna z jej biografii, książka Beaty Ostrowickiej Irena Sendlerowa. Magiczny koralik ukazała się nawet w serii „Polscy superbohaterowie”. Sendlerowa funkcjonuje w niej obok 
jako element narracji, innym razem w kalendarium. Ciekawym zabiegiem, mającym na celu nobilitację Sendlerowej w oczach dzieci, jest włączenie przez Annę Czerwińską-Rydel do książki Listy w butelce. Opowieść o Irenie Sendlerowej listów papieża Jana Pawła II oraz Rzecznika Praw Dziecka Marka Michalaka, w których wyrażaja oni uznanie dla postawy bohaterki w czasie wojny ${ }^{10}$. Autorzy publikacji dla dorosłych często przyznają że motywacją do napisania książki była możliwość uhonorowania Sendlerowej. Anna Mieszkowska pisze o niej jako o „żywym pomniku historii” ${ }^{11}$, z kolei Halina Grubowska deklaruje w posłowiu: „To, że mimo bohaterskiej działalności w czasie okupacji [Sendlerowa] pozostała w cieniu innych, spowodowało, że musiałam o niej napisać" 12 .

Książkę Sendlerowa. W ukryciu wyróżnia spośród innych wymienionych przeze mnie tekstów krytyczny stosunek autorki do utrwalonego wizerunku Ireny Sendlerowej. Wielu recenzentów dostrzegło polemiczny charakter biografii Bikont, pojawiały się jednak różnice w jego wartościowaniu. Część twierdziła, że tego rodzaju publikacja była społecznie potrzebna ${ }^{13}$, ale niektórzy wytykali Annie Bikont „małostkową próbę uwikłania biografii Ireny Sendler w bieżąca "politykę historyczną»" ${ }^{14}$. Tymczasem, jak zauważa Piotr Forecki, temat Polaków ratujących Żydów był elementem polityki historycznej już w PRL ${ }^{15}$. Współcześnie narracja o Polakach ratujacych Żydów stała się zaś elementem strategii, którą badacz określa mianem backlashu. Forecki definiuje ja jako jedną $z$ wielu defensywnych i zarazem konfrontacyjnych reakcji na publikację Sqsiadów Jana Tomasza Grossa i samą zbrodnię w Jedwabnem, wyrażoną w formie swoistej „polityki wobec pamięci”16, której celem jest wyeksponowanie pozytywnych aspektów polskości. Autor zaznacza, że tego rodzaju polityka prowadzi do instrumentalnego

takich postaci, jak Witold Pilecki, Józef Piłsudski czy Tadeusz Kościuszko, a także Maria Skłodowska-Curie.

${ }^{10}$ Por. A. Czerwińska-Rydel, dz. cyt., s. 92, 101.

${ }^{11}$ A. Mieszkowska, Matka dzieci Holocaustu..., s. 24.

${ }^{12}$ H. Grubowska, Ta, która ratowała Żydów. Rzecz o Irenie Sendlerowej, Warszawa 2014, s. 112.

${ }^{13}$ Por. B. Batosik, Bohaterka przeciwko legendzie, <http://wiez.com.pl/2017/10/30/bohaterka-przeciwko-legendzie/> [dostęp: 7.06.2019]; M. Cielecki, Anna Bikont. Sendlerowa. W ukryciu, <https://instytutksiazki.pl/literatura,8,recenzje,25, wszystkie,0,sendlerowa-w-ukryciu,92.html> [dostęp: 7.06.2019].

${ }^{14}$ P. Jędrzejewski, Brzydka próba uwiktania Ireny Sendlerowej. Szkoda, że Anna Bikont nie potrafita stanać ,,ponad”, <https://www.fronda.pl/a/jedrzejewski-brzydka-proba-uwiklania-ireny-sendlerowej-szkoda-ze-anna-bikont-nie-potrafila-stanac-ponad,101882.html> [dostęp: 7.06.2019].

${ }^{15}$ Por. P. Forecki, Po Jedwabnem. Anatomia pamięci funkcjonalnej, Warszawa 2018, s. 255.

${ }^{16}$ Por. tamże, s. 10. 
traktowania biografii poszczególnych osób. Podobną opinię można znaleźć w dwóch kolejnych tekstach poświęconych biografii Bikont, których autorki, Joanna Tokarska-Bakir i Paulina Małochleb, interpretuja ten tekst jako próbę przezwyciężenia mitu Ireny Sendlerowej ${ }^{17}$.

Nawiazując do zaproponowanej przez obie autorki interpretacji, chciałabym potraktować książkę Anny Bikont jako performans tekstualny. Termin ten najczęściej stosowany jest $\mathrm{w}$ odniesieniu do tekstów dla teatru ${ }^{18}$ oraz utworów literackich funkcjonujących w ramach takich wydarzeń, jak slam poetycki czy festiwal literacki ${ }^{19}$. Ostatnio pojawiają się próby performatywnego czytania innych tekstów, w tym także literatury dokumentu osobiste$\mathrm{go}^{20}$. Moja propozycja performatywnego odczytania Sendlerowej... czerpie z dwóch źródeł. Pierwszym z nich jest, wprowadzona przez Annę Burzyńską w odniesieniu do działalności pisarskiej Jacques'a Derridy, koncepcja performansu tekstualnego jako zabiegu „przeniesienia” cech performansu (widowiska) na praktyki „lekturopisarskie”"1. Drugie stanowi, sformułowane przez Annę Krajewska, ujęcie estetyki performatywnej:

Wychodzac z przekonania o dramatycznym i dialogicznym charakterze kultury i roli, jaką odgrywają w dyskursach różnych dyscyplin [...] pojęcie teatralne (dialogu, sceny, aktu, gry, odgrywania, imitacji, interakcji, agonu, parabazy, zdarzenia) proponuję antybinarne i nielinearne ujęcie estetyki, które kategorie literackości i performatywności pozostawiaja w „przeplocie”, w sferze szwu, krawędzi, styku, stale dialogując i rozgrywając ze sobą grę w sztukę (słowa i działania) ${ }^{22}$.

W zacytowanym fragmencie pojawiają się dwa kluczowe dla mojej interpretacji tekstu Bikont terminy: agon (rozumiany jako rywalizacja słowna, spór antagonistycznie do siebie nastawionych postaci) oraz działanie. Biografia Anny Bikont, jako przykład performansu tekstualnego, byłaby

${ }^{17}$ J. Tokarska-Bakir, Polska kolej podziemna - Sendlerowa dla dorostych, <http://wyborcza.pl/ksiazki/7,154165,22322905,polska-kolej-podziemna-sendlerowa-dla-doroslych.html> [dostęp: 7.06.2019]; P. Małochleb, Strategia księgowej, <http://malyformat.com/2018/06/strategia-ksiegowej/> [dostęp: 7.06.2019].

${ }^{18}$ Por. M. Sugiera, Pytania o dramat, „Teksty Drugie” 2005, nr 1-2, s. 60-71; A. Grabowski, Dramatu-pisanie jako performans. Zeznanie sprawcy, [w:] Performans, performatywność, performer. Próby definicji $i$ analizy krytyczne, red. E. Bal, W. Świątkowska, Kraków 2013, s. 97-106.

${ }^{19}$ Por. A. Kołodziej, Mowa w (s)tarciu $z$ pismem. Slam poetycki jako przyktad symbiozy tekstu i wydarzania, [w:] Performans, performatywność, performer. Próby definicji i analizy krytyczne, red. E. Bal, W. Świątkowska, Kraków 2013, s. 89-96; M. Czaja, Nowa humanistyka a performatywność literatury, <http://wakat.sdk.pl/nowa-humanistyka-a-performatywnosc-literatury/> [dostęp: 18.11.2019].

${ }^{20}$ Por. P. Kubkowski, „Dosyć nie umiem pisać”-Dzienniczek Faustyny Kowalskiej jako wydarzenie piśmienne i tekstowe, „Teksty Drugie” 2015, nr 4, s. 119-138.

${ }^{21}$ Por. A. Burzyńska, Dekonstrukcja, polityka i performatyka, Kraków 2013, s. 375.

${ }^{22}$ A. Krajewska, Dramatyczna teoria literatury. Zarys problematyki, Poznań 2009, s. 25. 
przede wszystkim działaniem za pomocą słów podejmowanym w sferze publicznej. Polega ono na tym, że autorka wdaje się w spór ze zwolennikami utrwalonego wizerunku Ireny Sendlerowej. Z uwagi na fakt, że postać ta była wykorzystywana przez twórców polskiej polityki historycznej, performans tekstualny jest w tym wypadku zarazem performansem politycznym. Ma on na celu nie tylko zmianę wizerunku jednej osoby, ale także krytykę instrumentalnego traktowania biografii wszystkich tych, którzy zostali uznani za bohaterów narodowych. Znaczenie i oddziaływanie są w tekście Anny Bikont nierozerwalnie złączone ${ }^{23}$, a związek ten, jak będę się starała udowodnić, nie tylko daje się zaobserwować w dyskursie krytycznoliterackim, ale wynika bezpośrednio z przyjętych przez autorkę strategii konstruowania narracji biograficznej.

Moja koncepcja politycznego performansu tekstualnego inspirowana jest ustaleniami Judith Butler z książki Żadanie Antygony. Butler pisze o Antygonie jako o osobie, która, wbrew społecznym oczekiwaniom, wypowiada się publicznie. Jej wypowiedzi mają status aktów mowy - Antygona działa za pomoca słów ${ }^{24}$. Warto zaznaczyć, że Butler swoją koncepcję performatywności zdecydowała się oprzeć zarówno na Austinowskiej teorii, jak i na Derridowskiej krytyce koncepcji Austina ${ }^{25}$. Wpływ myśli Jacques'a Derridy ujawnia się w jej stosunku do kwestii cytatowości (iterowalności) performatywów. Podczas gdy Austin wyróżnił pewną grupę wypowiedzi performatywnych z definicji pustych lub daremnych, ze względu na to, co nazywa „pasożytniczym użyciem języka” ${ }^{26}$, Derrida uznaje iterowalność za cechę performatywów w ogóle ${ }^{27}$. Judith Butler, nawiązując do myśli Derridy, zwraca uwagę na nierozerwalny związek między słowami-czynami Antygony a dyskursem, przeciwko któremu się ona opowiada: „Jej słowa, rozumiane jako czyny, pozostają chiazmicznie związane z żargonem suwerennej władzy - Antygona się nim posługuje, ale zarazem mówi przeciwko niemu [...] zasiedlając język suwerennej władzy dokładnie w tym samym momencie, w którym się przeciwko niej buntuje i zostaje wykluczona z ustalonego przez nią porządku”"28.

Antygona w interpretacji Butler cytuje wbrew konwencji. Posługuje się tym, co zostaje nazwane „żargonem suwerennej władzy”, nie po to, by

\footnotetext{
${ }^{23}$ Por. A. Burzyńska, dz. cyt., s. 438.

${ }^{24}$ Por. J. Butler, Żadanie Antygony, przeł. M. Borowski, M. Sugiera, Kraków 2010, s. 19.

${ }^{25}$ Por. A. Burzyńska, dz. cyt., s. 261.

${ }^{26}$ Por. J.L. Austin, Mówienie i poznawanie, przeł. B. Chwedończuk, Warszawa 1993,

${ }^{27}$ Por. J. Derrida, Sygnatura, zdarzenie, kontekst, [w:] tegoż, Pismo filozofii, przeł. B. Banasiak, Kraków 1993, s. 275.

${ }^{28}$ J. Butler, dz. cyt., s. 42.
} s. $170-171$. 
potwierdzić narzuconą sobie rolę społeczna, ale by ją zakwestionować. Zawłaszczając męski język, wchodzi w męską rolę ${ }^{29}$, a jednocześnie stawia się poza społecznością i skazuje na śmierć ${ }^{30}$. Zastosowanie tych obserwacji w odniesieniu do tekstu Anny Bikont wymaga, rzecz jasna, pewnych przekształceń. Performatywność Sendlerowej... jest z pewnością mniej wyraźna, gdyż kwestia funkcjonowania w przestrzeni publicznej nie zostaje w niej bezpośrednio stematyzowana. Różny jest też cel podejmowanych przez Annę Bikont działań, gdyż biografka nie walczy o własna pozycję społeczną, ale stara się zmienić wizerunek innej, ważnej dla Polaków postaci.

Autorka przyjmuje w tym celu strategię określoną przez Zofię Mitosek jako mimesis krytyczna. Badaczka w opisie tej kategorii odnosi się przede wszystkim do twórczości dwudziestowiecznych artystów awangardowych. Charakteryzuje jąjako „postawę twórczą której odpowiadają określone techniki mimetyczne: cytat, cudzysłów, parodia, ironia (przez przywołanie) ${ }^{31}$. Zofia Mitosek zaznacza, że w utworach Witkacego i Eugene'a Ionesco cytowanie ma charakter parodystyczny i demaskatorski, jest praktyką dystansowania się wobec gotowych form mówienia ${ }^{32}$. W wypadku tekstu Anny Bikont zasada jest podobna - biografka cytuje elementy dyskursu, przeciwko któremu się opowiada, by go ostatecznie zakwestionować. Dyskursem tym, owa, wspomnianą przez Zofię Mitosek, „gotową formą mówienia” jest w tym wypadku heroizująca narracja o Polakach ratujących Żydów. Anna Bikont skupia się na jednym z elementów tej narracji - na utrwalonym wizerunku Ireny Sendlerowej. Nazywam go, za Michaelem Bentonem, biomitografia [biomythography] ${ }^{33}$.

W książce Literary Biography. An Introduction pojęcie biomitografii pojawia się początkowo jako synonim biografii pisarzy (sióstr Brontë czy George'a Byrona). Benton podkreśla, że autorzy tego rodzaju tekstów muszą odnieść się nie tylko do faktów, ale także do autokreacji, której często dokonują ich bohaterowie ${ }^{34}$. W dalszym ciagu wywodu biomitografia staje się określeniem kulturowo utrwalonego wizerunku, funkcjonującego w oderwaniu od faktów. Szczególnie istotne jest, jak się zdaje, jedno sformułowanie z końcowej części tekstu: „Powstawanie biomitografii polega na gromadzeniu i organizowaniu rozproszonych fragmentów przeszłości w celu zaspokojenia potrzeb współczesnych [osób i wspólnot]”"35.

\footnotetext{
${ }^{29}$ Por. tamże, s. 21.

${ }^{30}$ Por. tamże, s. 41.

${ }^{31}$ Z. Mitosek, Mimesis krytyczna, „Pamiętnik Literacki” 1988, z. 3, s. 89.

${ }^{32}$ Por. tamże, s. 90.

${ }^{33}$ Por. M. Benton, Literary Biomythography, [w:] tegoż, Literary Biography. An Introduction, Hoboken 2015, s. 48.

${ }^{34}$ Por. tamże.

${ }^{35}$ Por. tamże, s. 65. Wszystkie cytaty z książki Michaela Bentona podaję w moim tłu-
} maczeniu. 
Zdecydowałam się posłużyć kategorią biomitografii w odniesieniu do dominującej narracji biograficznej o Irenie Sendlerowej z dwóch powodów. Po pierwsze, bohaterka pozostawiła wiele wypowiedzi o charakterze autobiograficznym: wspomnień, zeznań, wywiadów czy listów. Z czasem dokonywała także coraz bardziej świadomej i daleko idacej autokreacji. Istotnym elementem tych zabiegów była biografia Anny Mieszkowskiej, która, jak przekonuje Anna Bikont, jest de facto autobiografią bohaterki, napisaną na podstawie dostarczanych przez nią materiałów. Po drugie, w ciagu ostatnich kilkunastu lat, kiedy Irena Sendlerowa stała się symbolem polskich Sprawiedliwych, jej wizerunek coraz bardziej oddalał się od faktycznej historii jej życia, ulegając daleko idącej mitologizacji.

Michael Benton proponuje następujący schemat powstawania biomitografii:

1) działania pierwszego biografa, który - na podstawie zebranych i wyselekcjonowanych przez siebie informacji - prezentuje historię życia bohatera zgodną z jego własną interpretacją faktów;

2) fikcjonalizacja faktów, zarówno poprzez umieszczenie ich w autobiograficznych tekstach samego bohatera, jak i na skutek działań biografa;

3) mitologizacja fikcji, w wyniku której postacie oraz miejsca z nimi związane staja się symbolami;

4) przekształcenie się mitu w wiele różnorodnych, częściowo opartych na faktach, ale ubarwionych elementami fikcyjnymi narracji [factions];

5) działania współczesnych biografów, którzy próbują odwrócić proces mitologizacji biografii poprzez powrót do źródeł bezpośrednich ${ }^{36}$.

W kontekście biomitografii Sendlerowej warto zauważyć, że działania autokreacyjne bohaterki wyprzedzaja biografię Mieszkowskiej o kilkadziesiąt lat. Ich początek datuje się na lata sześćdziesiąte, kiedy w „Biuletynie Żydowskiego Instytutu Historycznego” po raz pierwszy ukazały się wspomnienia Sendlerowej z czasów okupacji ${ }^{37}$. Biografię Anny Bikont od pierwszego wydania tekstu Anny Mieszkowskiej w 2004 roku dzieli zaledwie trzynaście lat. Nie zmienia to faktu, że działania Anny Bikont stanowią realizację piątego punktu schematu, są bowiem próbą demitologizacji biografii Sendlerowej przez konfrontację mniej lub bardziej zmityzowanych narracji o jej życiu z tym, co Michael Benton określa mianem „źródeł bezpośrednich” [primary sources] ${ }^{38}$. Mam tu na myśli dokumenty zgromadzone w archiwach (Archiwum Yad Vashem, Archiwum ŻIH, Visual History Archives, Shoah Foundation) oraz wypowiedzi bohaterki i jej współpracowniczek sprzed

\footnotetext{
${ }^{36}$ Por. tamże, s. 53.

${ }^{37}$ Por. I. Sendlerowa, Ci, którzy pomagali Żydom. (Wspomnienia z czasów okupacji hitlerowskiej), „Biuletyn Żydowskiego Instytutu Historycznego” 1963, nr 45-46, s. 234-247.

${ }^{38}$ Por. M. Benton, dz. cyt., s. 53.
} 
2000 roku, kiedy zainteresowanie jej osoba gwałtownie wzrosło w związku z popularnością sztuki Life in a jar w Stanach Zjednoczonych ${ }^{39}$. Dane znalezione w archiwach Bikont uzupełnia o informacje zebrane podczas rozmów z ocalałymi z Zagłady, tzw. „dziećmi Ireny Sendlerowej”, m.in. Michałem Głowińskim, Katarzyną Meloch czy Ireną Wojdowska.

Zgodnie z zasadą mimesis krytycznej Anna Bikont cytuje fragmenty istniejącego dyskursu o Sendlerowej po to, by go zakwestionować. Relacja między książką Bikont a biografią autorstwa Anny Mieszkowskiej jest, jak się zdaje, analogiczna do tej między Trylogia Sienkiewicza a Nienasyceniem Witkacego, scharakteryzowanej przez Zofię Mitosek w następujący sposób:

W Nienasyceniu nieomal wszystkie zwroty, które tworzyły aurę patriotyczną Trylogii, funkcjonują jako cytaty. „Ojczyzna”, „przedmurze” (także „przedmurzyzm”), „druhowie”, „wódz” (i „u boku wodza”) - tak zapisane wyrażenia informują w o wiele większym stopniu o określonej tradycji i kulturze (literackiej, narodowej), kompromitując ją zarazem, aniżeli o przebiegu fabuły $[\ldots]^{40}$.

Podobnie jak Witkacy, który wykorzystywał charakterystyczne sformułowania z powieści Sienkiewicza w celach parodystycznych, Anna Bikont posługuje się cytatami z biografii Mieszkowskiej. Autorka wynotowuje i włącza do swojego tekstu cytat: „Jest matką dwóch i pół tysiąca dzieci uratowanych z warszawskiego getta. Nie używam słowa "przybrana» matka, ale właśnie matka, ponieważ dała im życie po raz drugi” $(S, 403)^{41}$. Cytat ten umieszcza w kontekście swoich rozważań o liczbie dwóch i pół tysiąca dzieci, które Irena Sendlerowa rzekomo miała uratować. Liczba ta jest, jej zdaniem, mocno zawyżona i niewiarygodna, zważywszy na skromne finanse Żegoty oraz fakt, że organizacja mogła udzielać pomocy dzieciom żydowskim jedynie przez siedem i pół miesiąca ${ }^{42}$. W tym miejscu najpełniej uwidacznia się agonistyczny charakter biografii Bikont. Cytując Mieszkowska, podejmuje z nią zarazem słowną rywalizację - działanie, które ma na celu zakwestionowanie wiarygodności jej tekstu, a jego autorkę sytuuje na pozycji Bentonowskiego „pierwszego biografa”, który nie tylko interpretuje fakty, ale także współkonstruuje mit.

Biografia Anny Mieszkowskiej jest w dużej mierze oparta na materiałach dostarczonych przez samą Irenę Sendlerową. Znaczną część tekstu stanowią cytaty z różnego rodzaju wypowiedzi bohaterki: rozmów z biograf-

${ }^{39} \mathrm{Na}$ temat sztuki i jej autorek, czterech uczennic z miasteczka Uniontown, por. J. Mayer, Życie w stoiku. Ocalenie Ireny Sendlerowej, przeł. R. Stiller, Warszawa 2013.

${ }^{40}$ Z. Mitosek, dz. cyt., s. 89.

${ }^{41}$ Cytaty z tekstu biografii Anny Bikont oznaczam literą S, liczba za nią wskazuje na numer strony.

${ }^{42}$ Por. A. Bikont, Sendlerowa. W ukryciu, Wołowiec 2017, s. 402. 
$\mathrm{ka}^{43}$, relacji opublikowanych w „Biuletynie Żydowskiego Instytutu Historycznego" ${ }^{44}$, listów ${ }^{45}$, wywiadów ${ }^{46}$; a także fragmenty jej rękopiśmiennych wspomnien ${ }^{47}$. Warto zauważyć, że narracje biografki i bohaterki przeplataja się i wzajemnie uzupełniaja. Anna Mieszkowska nie odnosi się krytycznie do słów Sendlerowej, a zwłaszcza nie próbuje weryfikować podawanych przez nią faktów. Tymczasem to właśnie sama Irena Sendlerowa zostaje wskazana przez Annę Bikont jako osoba, która najbardziej przyczyniła się do fikcjonalizacji własnego wizerunku. Dotyczy to zwłaszcza kwestii wynoszenia czy też wyprowadzania przez nią osobiście dzieci z getta. Bikont podkreśla, że Sendlerowa opowiedziała mnóstwo podobnych historii, a one bardzo szybko utrwaliły się w społecznej świadomości:

Sendlerowa wiele razy opisywała sposoby wywożenia małych dzieci. Karetką Wydziału lub przez zajezdnię tramwajową na Muranowie, ponieważ mąż jednej z jej koleżanek był motorniczym. I właśnie z tym ją kojarzymy - z heroicznym wynoszeniem małych dzieci z getta. To standard pisania o niej. Już sam jej wygląd, gdy stało się o niej głośno, łagodnej siwiutkiej starszej pani, wywołuje takie asocjacje. Nic więc dziwnego, że o takie poruszające historie ją pytano, a ona je opowiadała. Z pewnością zdarzyło się, że jej koleżanki, zaprzyjaźniony szofer pojazdu sanitarnego czy tramwajarz wyprowadzili lub wywieźli z getta żydowskie dziecko. Ale w akcji pomocy takie przypadki były sporadyczne. Żydzi znali bez porównania lepiej niż Polacy sposoby wydostania się z getta. Natomiast pomoc Polaków była bezcenna po drugiej stronie muru (S, 102).

Zacytowany fragment dobrze pokazuje odmienność tekstu Anny Bikont od pozostałych biografii. Odwrotnie niż Anna Mieszkowska czy Halina Grubowska, które bez żadnego komentarza włączają cytaty z wypowiedzi Ireny Sendlerowej do swoich tekstów, Bikont te właśnie opowieści, powtarzane tyle razy, że stały się już kliszami, czyni przedmiotem refleksji. W ten sposób demaskuje zwiazane z bohaterka przyzwyczajenia odbiorcze - opowieść o niej, w opinii wielu, musi być historia kobiety wynoszącej małe dzieci z getta. Anna Bikont nie tylko czyni przedmiotem refleksji spetryfikowane elementy biografii Sendlerowej, ale przede wszystkim świadomie i konsekwentnie ustawia się w pozycji reportera - osoby, która ma obowiązek zweryfikowania podawanych przez bohaterkę informacji w innych źródłach. W wypadku opowieści o wyprowadzanych z getta dzieciach biografka zdecydowała się sięgnać po wywiad Romualda Teyszerskiego z Jadwigą Piotrowską ${ }^{48}$, jedną ze współpracowniczek bohaterki.

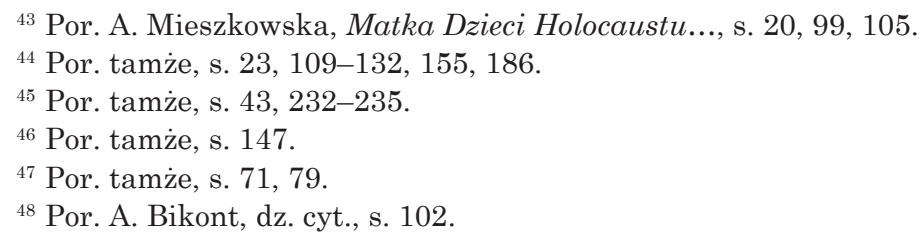


W tych fragmentach biografii Bikont, w których autorka odnosi się do historii ratowania żydowskich dzieci, można dostrzec performatywność jej tekstu. Cecha ta wyraża się nie tylko w cytowaniu opowieści Sendlerowej po to, by zakwestionować ich historyczną wartość. Bikont często stosuje także strategię konfrontowania różnych wersji tej samej historii, zamieszczonych w kilku źródłach:

Irena Sendlerowa opowiedziała Elżbiecie historię jej wyjścia z getta niedługo przed swoją śmiercią. Tę historię o Elżuni i Piotrusiu, przyprowadzonych do niej po przejściu przez kanał, tak brudnych, że musiała w nocy pożyczać mydło. Nigdy wcześniej ani jej, ani nikomu z rodziny nie powiedziała, że owa opowieść, która powtarzała od lat, jest o nich. Elżbieta zdzwoniła się z Piotrem i ustalili, że to nie mogło się im przydarzyć [...].

Kuzynowie nie wychodzili bowiem z getta sami, ale pod opieka Marii Szpilfogel, mamy Elżuni. Piotra ktoś musiał zabrać, one dwie trafiły, jak było umówione, do Julii Elżanowskiej-Dąbrowskiej, przyjaciółki Marii. Elżbiecie zostało niejasne wspomnienie ciemności, smrodu, pamięta, jak ktoś ją niósł na barana, brodząc w mazi, i jak ocknęła się w mieszkaniu Dąbrowskiej.

Nie jest to zatem historia Piotra i Elżbiety. Pierwszy raz Sendlerowa opublikowała ją w „Biuletynie ŻIH-u” w 1981 roku, ale napisała o czworgu dzieciach, nie o dwojgu, przyprowadzonych o trzeciej nad ranem (dla trzeciego z nich zabrakło mydła), i nie do niej, lecz do koleżanki z konspiracji. Może to więc historia którejś z jej współpracowniczek? A może zdarzyła się jej, tylko z innymi dziećmi i w innym czasie? [...]. Maria Szpilfogel i Elżunia nie zetknęły się z Sendlerową w czasie wojny. Poznały ją dopiero w latach sześćdziesiątych przez mamę Michała Felicję Głowińska (S, 130-131).

Dzięki zastosowaniu strategii konfrontowania różnych wersji tej samej historii stworzona przez Bikont narracja biograficzna zyskuje odmienny status, niż to ma zwykle miejsce w biografiach rozumianych jako opowieść o życiu i twórczości. Nie jest już ona uporządkowanym chronologicznie zapisem tego, co biografowi udało się ustalić. Wydarzenia pojawiają się w takiej kolejności, w jakiej dowiadywała się o nich autorka, biografce zależy bowiem na pokazaniu procesu dochodzenia do prawdy i zakwestionowaniu fikcyjnej wersji wydarzeń bardziej niż na podaniu własnej wersji, uspójnionej na potrzeby tworzonego tekstu. Ujawnia się tutaj jedna z bardzo charakterystycznych cech performansu tekstualnego, jaką jest wytwarzanie się znaczeń in statu nascendi $\mathrm{w}$ samym tekście ${ }^{49}$. Biografia Bikont wykazuje tutaj także pewne podobieństwo do tych tekstów, które są uważane za klasyczne przykłady performansów tekstualnych, owych powieści-labiryntów, które, jak to ujmuje Erika Fischer-Lichte, „z czytelnika czynią autora, gdyż oferują

${ }^{49}$ Por. A. Burzyńska, dz. cyt., s. 386.

\begin{tabular}{l|l} 
Paulina Żarnecka & $\mathbf{1 5 6}$
\end{tabular} 
mu materiał do samodzielnego układania"50. Takie utwory, jak Gra w klasy Julio Cortázara, Rzut kośćmi Stéphane Mallarmégo czy hipertekstowy Blok Sławomira Shutego są bowiem w samym założeniu nieskończone, a ich struktura może być współtworzona przez czytelnika ${ }^{51}$. W wypadku tekstu Anny Bikont chodzi nie tyle o nieskończoność struktury, ale o pojawienie się kilku, wzajemnie się wykluczających, znaczeń tego samego fragmentu narracji biograficznej, w wyniku podania przez autorkę kilku równie prawdopodobnych wersji zdarzeń - bohaterką historii o uratowanych z getta dzieciach może być równie dobrze sama Sendlerowa, co jedna z jej współpracowniczek. Taki sposób konstruowania narracji biograficznej ma przy tym ten sam cel, który towarzyszył powstawaniu eksperymentalnej powieści Cortázara - przemodelowanie charakteru lektury tekstu literackiego. Staje się ona odtąd twórczym działaniem, którego efekty będą w wypadku każdego czytelnika inne, w zależności od tego, na ile jest on w stanie przyjąć alternatywną wobec tej najbardziej rozpowszechnionej wersję zdarzeń.

Tryb sprawozdania i autorytatywne przedstawienie alternatywnej w stosunku do tego, co opowiadała sama bohaterka, wersji zdarzeń, w tekście Bikont obecne jest wyłącznie wówczas, gdy ma ona możliwość odwołania się do materiałów archiwalnych. Tak jest w wypadku historii uwięzienia Sendlerowej na Pawiaku:

Sendlerowa na użytek pisanych przez siebie życiorysów, udzielanych wywiadów i autoryzowanej biografii podawała różne informacje o swoim uwięzieniu, w tym różny czas pobytu na Pawiaku, od trzech do pięciu miesięcy. Uwiarygodniała te opowieści rozmaitymi szczegółami, na przykład, że była wiosna, kiedy wyszła $\mathrm{z}$ aresztu (chociaż był listopad).

To wiemy na pewno: była więźniarką Pawiaka między 18 października a 13 listopada 1943 roku [tu przypis do Akt Klubu b. Więźniów Politycznych Pawiaka - uwaga moja - P.Ż.]. [...] Została wypuszczona dzięki łapówce, którą wpłaciła Żegota (S, 226).

Sformułowanie „to wiemy na pewno”, po którym następuje wyliczenie dat i faktów, pojawia się u Bikont rzadko. Tym samym jej tekst po raz kolejny okazuje się działaniem krytycznym, nastawionym przede wszystkim na wyeksponowanie sprzeczności i niejasności w najbardziej znanym okresie życia Sendlerowej.

Rozprawiwszy się z działaniami autokreacyjnymi samej bohaterki, Anna Bikont odnotowuje okres, w którym następuje mityzacja jej postaci, a mit staje się elementem narracji o Polakach ratujących Żydów, wykorzystywanej

${ }^{50}$ Por. E. Fischer-Lichte, Estetyka performatywności, przeł. M. Borowski, M. Sugiera, Kraków 2008, s. 25.

${ }^{51}$ Por. J. Woźniak, Performatyka wobec koncepcji dzieła w toku, [w:] Zwrot performatywny w kulturze. Szkice o obyczajach, literaturze, performansie i tańcu, red. M. Błaszczak, I. Górska, Poznań 2015, s. 24. 
w celach politycznych. Według biografki mityzacja Sendlerowej jest ściśle związana z kryzysem w polskiej polityce historycznej po publikacji książki Jana Tomasza Grossa Sqsiedzi...52. Proces ten polega na takim przekształcaniu biografii Sendlerowej, by przykroić go do obowiązującego schematu:

Gdy po Sasiadach Grossa powstawały kolejne książki i filmy odsłaniajace polsko-żydowską wojenną przeszłość, „zapotrzebowanie” na Irenę Sendlerową wzrastało. Miała stać się twarzą Polski czasu wojny. W prasie rozpisywano się o tym, jak komunistyczny reżim skazał ją na zapomnienie. [...]

Pisząc o Sendlerowej, celowo pomijano lub zamazywano czasy PRL-u, a także wyolbrzymiano jej prześladowania, bo pasowało to do obowiązującego od lat dziewięćdziesiątych stereotypu bohatera RP [...].

Historia Sendlerowej musiała zostać przekłamana, by można ją było wtłoczyć w pożądaną narrację prawicowo-narodowa, obowiąująca w polityce historycznej od wielu lat. Bohater ma być ulepiony z katolicko-narodowego kruszcu i reprezentować Polskę walcząca, ciemiężoną przez hitlerowskiego i sowieckiego najeźdźcę. Tymczasem, gdy odejść od narzuconego paradygmatu i spojrzeć na nią jak na człowieka lewicy, którym zawsze była, puzzle zaczynają się same układać (S, 378, 380).

Obserwacje Anny Bikont, zawarte w tym fragmencie, można również znaleźć w wielu publikacjach dotyczących polskiej polityki historycznej. Jest to, po pierwsze, przełomowe znaczenie publikacji Sqsiadów... Jana Tomasza Grossa dla rozwoju specyficznej, autoafirmacyjnej polityki historycznej w Polsce ${ }^{53}$. Po drugie zaś - wykorzystywanie biografii niektórych osób, zasłużonych dla ratowania Żydów do odparcia zarzutów o udział Polaków w Zagładzie ${ }^{54}$. Jeden z badaczy polskiej polityki historycznej, Michał Łuczewski, proponuje określenie sytuacji, w której znalazła się ona na prze-

52 J.T. Gross, Sasiedzi. Historia zagłady żydowskiego miasteczka, Sejny 2000.

${ }^{53}$ Tego rodzaju tezę można znaleźć w cytowanej już przeze mnie książce Piotra Foreckiego, a także w innych publikacjach. Por. M. Łuczewski, Kapitał moralny. Polityki historyczne w późnej nowoczesności, Kraków 2017, s. 207. Ich autorzy zaznaczają przy tym, że rozwój swoistej, autoafirmacyjnej polityki wobec pamięci nie był pierwszą reakcją na pojawienie się w polskim dyskursie publicznym tematu zbrodni w Jedwabnem, ale rozpoczą się dopiero w roku 2004, w roku otwarcia Muzeum Powstania Warszawskiego i tuż przed wygranymi przez PiS wyborami w roku 2005. Lech M. Nijakowski rozwój polityki pamięci, obliczonej na propagowanie pozytywnej wizji dziejów Polski, traktuje jako część „ofensywy martyrologicznej IV RP”. Por. L.M. Nijakowski, Polska polityka pamięci. Esej socjologiczny, Warszawa 2008, s. 190, 201-204.

${ }^{54}$ Szczegółowo opisuje to zjawisko Maria Kobielska na przykładzie instrumentalnego potraktowania losów rodziny Ulmów przez twórców Muzeum Polaków Ratujących Żydów podczas II wojny światowej im. Rodziny Ulmów w Markowej. Por. M. Kobielska, Polska pamięć autoafirmacyjna, „Teksty Drugie” 2016, nr 6, s. 358-374. Biografie Polaków ratujących Żydów są także, jak zauważa Katarzyna Kącka, wykorzystywane w celu usprawiedliwienia pogromu kieleckiego. Por. K. Kącka, Polityka historyczna: kreatorzy, narzędzia, mechanizmy działania, [w:] Narracje pamięci. Między polityka a historia, red. K. Kącka, J. Piechowiak-Lamparska, A. Ratke-Majewska, Torun 2015, s. 76. 
łomie wieków, mianem „utraty kapitału moralnego" ${ }^{55}$. Opisuje on działania po ujawnieniu sprawy Jedwabnego w kategoriach wypierania konwersji (powrotu do przeszłości nastawionego na to, by się od niej odciąć), przez narrację resourcement. Narrator tego rodzaju opowieści (podmiot kreujący politykę historyczna) nie może utożsamić się ze sprawca, ale może się w nim rozpoznać i wziąć odpowiedzialność za jego czyny ${ }^{56}$. Zdaniem Michała Łuczewskiego tego rodzaju narracja, która pojawiała się dość często w kilku pierwszych latach po publikacji książki Grossa, została następnie wyparta przez narrację heroiczna:

Na koniec zwróćmy uwagę na ostatnie źródło kapitału moralnego: konwersję. Sprawa Jedwabnego sprawiła, że tego typu opowieść moralna stała się naraz jedna z głównych polskich opowieści moralnych. Budowa M[uzeum] P[owstania] W[arszawskiego] miała temu przeciwdziałać [...].

Polacy zatem nie byli współwinnymi Holocaustu i to właśnie miało pokazać MPW. Ale nawet w Muzeum II Wojny Światowej i Muzeum POLIN narracja konwersji jest obecna tylko na marginesie. Mimo że w debacie publicznej Paweł Machcewicz zdecydowanie opowiadał się za tym, żeby ujmować Jedwabne obok Westerplatte i artykułował bardzo silną narrację konwersji, w MIIWŚ stanowiła ona „absolutny margines" całej ekspozycji i została umieszczona na tle różnych postaw społeczeństwa polskiego, w tym postaw bohaterskich (Irena Sendlerowa) ${ }^{57}$.

Nazwisko Ireny Sendlerowej nieprzypadkowo pojawia się w kontekście promowania określonej pamięciowej narracji przez instytucje państwowe. Jak zauważa Piotr Forecki:

[...] po wygranych w 2015 roku przez PIS wyborach prezydenckich i parlamentarnych instrumentalne traktowanie Polaków ratujących Żydów jeszcze się spotęgowało. Zostało również w pełni upaństwowione i zinstytucjonalizowane. [...]

Zarówno Jan Karski, jak i Irena Sendlerowa to nie sa już bohaterowie indywidualni. Mocą nadanej im funkcji oboje stali się ikonami polskich Sprawiedliwych, ludźmi bez własnych biografii. Uczyniono ich uosobieniem postaw wszystkich Polaków pod okupacją $[\ldots]^{58}$.

W odpowiedzi na instrumentalne potraktowanie biografii Sendlerowej przez państwowe instytucje oraz niektóre media Anna Bikont przywraca do życiorysu swojej bohaterki wszystko to, co zostało z niego wymazane w procesie mityzacji: niechętny stosunek do Kościoła, dobrowolne i ponadczterdziestoletnie członkostwo w partii oraz to, że „nie należała do AK i nigdy tego nie sugerowała" (S, 378). Przypomina, że Sendlerowa została uformowana przez środowisko Sekcji Pomocy Matce i Dziecku, a zwłasz-

\footnotetext{
${ }^{55}$ Por. M. Łuczewski, dz. cyt., s. 207.

${ }^{56}$ Por. tamże, s. 125.

${ }^{57}$ Tamże, s. 242.

${ }^{58}$ P. Forecki, dz. cyt., s. 299-300.
} 
cza przez jej przewodnicząca, Heleną Radlińską ${ }^{59}$. Gest zakwestionowania oficjalnego wizerunku bohaterki poprzez przywrócenie jej indywidualnej biografii jest kolejnym przejawem agonistycznego charakteru tekstu Bikont. Eksponowanie przez autorkę lewicowego światopoglądu Ireny Sendlerowej można potraktować jako część politycznego performansu tekstualnego, gest sprzeciwu wobec praktyki wtłaczania jej w prawicowo-narodową narrację. Polityczność tekstu Anny Bikont nie ogranicza się jednak do przypomnienia niewygodnych z punktu widzenia prawicowych polityków wydarzeń z życia Sendlerowej. Biografka decyduje się przy tej okazji także podważyć istotną zasadę funkcjonowania swojej wspólnoty, czyli strategię instrumentalnego traktowania wojennych losów jednostek przez polskich polityków w celu odwrócenia uwagi opinii publicznej od możliwego udziału Polaków w Zagładzie. To właśnie ta strategia, jeden z elementów backlashu - defensywnej reakcji na zbrodnię w Jedwabnem ${ }^{60}$, jest w tym wypadku „żargonem suwerennej władzy"61, o którym wspomina Judith Butler.

Tego, że Anna Bikont nie zamierza podtrzymywać mitu o powszechnej i bezinteresownej pomocy udzielanej Żydom przez Polaków w czasie wojny, czytelnik dowiaduje się już podczas lektury pierwszego rozdziału. Bikont opowiada w nim historię Margarity Turkow - dziewczynki przechowywanej przez Stanisławę Borcińska, osobę brutalną i bezwzględna, która szantażowała jej ojca, żeby na udzieleniu jej schronienia podwójnie zarobić. Autorka wielokrotnie podkreśla, że w warunkach okupacyjnych bezinteresowna pomoc często nie była możliwa ze względu na brak środków na utrzymanie kolejnej osoby. Gdy pisze o działalności tzw. „łączniczek Sendlerowej” - kilku kobiet z nią współpracujących, dysponujących środkami z Żegoty - wyraźnie akcentuje rolę tych pieniędzy w zapewnianiu dzieciom schronienia: „Na początku pieniędzy było mało, ale dawało się już wynajmować dorosłym mieszkania po aryjskiej stronie (udając, gdy tylko było możliwe, że nie chodzi o Żydów), a dla dzieci znajdować rodziny chcace ulżyć swojej biedzie i gotowe wziąć lub przechować dziecko, za którym szły pieniądze” (S, 142). Bikont opisuje funkcjonowanie dzieci oraz ich opiekunów w kategoriach „wojny polsko-polskiej”. Jej zdaniem to niedyskretne uwagi polskich sasiadów były najczęstszym powodem nieustannego przenoszenia podopiecznych $\mathrm{z}$ jednej rodziny do drugiej ${ }^{62}$. W ten sposób autorka podważa przekonanie o powszechności pomocy udzielanej Żydom przez Polaków, przywracając Sendlerowej i jej współpracownikom należny im status wybitnych jedno-

\footnotetext{
${ }^{59}$ Por. A. Bikont, dz. cyt., s. 61-64; 380.

${ }^{60}$ Por. P. Forecki, dz. cyt., s. 10.

${ }^{61}$ Por. J. Butler, dz. cyt., s. 42.

${ }^{62}$ Por. A. Bikont, dz. cyt., s. 209.
} 
stek, które w okupacyjnych realiach wykazały się rzadkim - i tym bardziej godnym uznania - heroizmem ${ }^{63}$.

Ostatnim elementem biomitografii sa factions - częściowo oparte na faktach narracje o Sendlerowej, występujace w różnych mediach. Z filmem Dzieci Ireny Sendlerowej rozprawia się w sposób szybki i bezwzględny, traktuje go bowiem jako hollywoodzki kicz, nieliczący się z prawdą historyczna. Nieco więcej uwagi autorka poświęca sztuce $\dot{Z} y c i e ~ w$ słoiku, a zwłaszcza dziejom znajomości jej autorek, uczennic z Uniontown, z Sendlerowa. W ich projekcie dostrzega wyraz autentycznej ciekawości poznawczej dziewcząt. Obecność mitów (np. historii o zakopanych w słoiku karteczkach z nazwiskami dzieci) w sztuce wynikać miała z tego, że Irena Sendlerowa nie wyprowadziła autorek z błędu ${ }^{64}$, a one nie były w stanie zweryfikować jej wersji ze względu na niemożność skonfrontowania jej ze źródłami, w większości polskojęzycznymi.

Performatywność tekstu Anny Bikont polega zatem na umiejętnym wykorzystaniu tej odmiany pisarstwa biograficznego, jaką jest reportaż biograficzny ${ }^{65}$, w celu zakwestionowania założeń współczesnej polskiej polityki historycznej. Biografia Ireny Sendlerowej zyskuje w jej tekście walor aktualności ze względu na znaczenie tej postaci dla polskiej wspólnoty narodowej. Zakwestionowanie biomitografii Sendlerowej umożliwia Annie Bikont usytuowanie się w kontrze do narracji o Polakach ratujacych Żydów jako elementu pojedwabieńskiego backlashu. W tym sensie działanie krytyczne Anny Bikont skierowane jest przede wszystkim wobec dzia-

${ }^{63}$ Podobny sposób ujęcia relacji polsko-żydowskich w czasie II wojny światowej można znaleźć w prologu Jacka Leociaka do książki Ratowanie. Opowieści Polaków i Żydów. Jej autor stwierdza: „Heroizm nie jest normą społeczną i nie wyznacza powszechnie obowiązujących standardów zachowania. [...] Jeśli nie chcemy tego uznać, sprzeniewierzamy się pamięci Sprawiedliwych i pograżamy w odmętach banału". J. Leociak, Ratowanie. Opowieści Polaków $i \dot{Z} y d o ́ w$, Kraków 2010, s. 13-14.

${ }^{64}$ Autorka zaznacza, że Sendlerowa sama poprawiała „naiwnie wzruszającą sztukę". Por. A. Bikont, dz. cyt., s. 366.

${ }^{65} \mathrm{~W}$ literaturze przedmiotu funkcjonuje równolegle kilka określeń tekstu, który pod względem gatunkowym sytuuje się na pograniczu reportażu i biografii, m.in. „biografia reporterska (reportażowa)” oraz „reportaż biograficzny”. W odniesieniu do książki Anny Bikont posługuję się terminem „reportaż biograficzny” w tym znaczeniu, jakie proponuje Edyta Żyrek-Horodyska. Charakteryzuje ona reportaż biograficzny jako tekst dziennikarski wyróżniający się szczególnym zorientowaniem wokół losów wybranego przez dziennikarza bohatera. Cechą odróżniająca go od biografii jest, zdaniem autorki, nacisk na aktualność przekazu oraz usytuowanie opowieści o losach postaci w określonym, ważnym dla odbiorcy kontekście. Por. E. Żyrek-Horodyska, Reportaż biograficzny czy biografia reportażowa? Refleksje genologiczne i analiza przypadku, „Autobiografia” 2018, nr 2, s. 168-169. W wypadku książki Bikont kontekstem tym jest wykorzystanie biografii Sendlerowej w narracji pamięciowej o Polakach ratujących Żydów. 
łań instytucji państwowych, m.in. Muzeum Polaków Ratujących Żydów im. Rodziny Ulmów w Markowej, jako urządzeń polskiej pamięci autoafirmacyjnej ${ }^{66}$, a dopiero w drugiej kolejności wobec działań autorów dzieł takich, jak film Matka dzieci Holocaustu, którzy wykorzystują fakty z życia Ireny Sendlerowej w celach komercyjnych. Reportaż biograficzny sprzyja tworzeniu pełnej sprzeczności i niejasności narracji biograficznej. Stanowi ona raczej zapis działań podjętych przez autorkę w celu ustalenia prawdy na temat pewnego etapu życia bohaterki, jakim była akcja ratowania żydowskich dzieci, niż spójną narrację biograficzną. Irena Sendlerowa, taka jak ja przedstawia Anna Bikont, nie ma przy tym cech ani polskiego bohatera narodowego, ani pielęgniarki. Nie realizuje także społecznych oczekiwań wobec kobiety - jest genialną organizatorka, ale nieszczęśliwą żoną i nie najlepszą matka.

Skuteczność podjętej przez Annę Bikont próby zakwestionowania biomitografii Ireny Sendlerowej jest obecnie trudna do ocenienia. Stworzony przez nią performans tekstualny zatrzymał się, jak się zdaje, na etapie sformułowania żądania. Jego skuteczność będzie w dużej mierze zależała od nastawienia czytelników. To oni zdecyduja, czy są w stanie zaakceptować nie tylko odmienny od dominującego wizerunek samej Sendlerowej, ale także prezentowany przez biografkę obraz wojennych i powojennych relacji polsko-żydowskich. Zadanie jest z pewnością niełatwe, biorąc pod uwagę ogromną popularność wizerunku „matki dzieci Holocaustu” w różnych mediach. O tym, czy Anna Bikont odniosła przynajmniej częściowy sukces, można będzie się przekonać na podstawie wizerunku Ireny Sendlerowej w tekstach kultury, które powstaną w kolejnych latach.

\section{BIBLIOGRAFIA PODMIOTOWA}

Bikont A., Sendlerowa. W ukryciu, Wołowiec 2017.

\section{BIBLIOGRAFIA PRZEDMIOTOWA}

Austin J.L., Mówienie i poznawanie, przeł. B. Chwedończuk, Warszawa 1993.

Batosik B., Bohaterka przeciwko legendzie, <http://wiez.com.pl/2017/10/30/bohaterka-przeciwko-legendzie/> [dostęp: 7.06.2019].

Benton M., Literary Biography. An Introduction, Hoboken 2015.

Burzyńska A., Dekonstrukcja, polityka i performatyka, Kraków 2013.

Butler J., Żadanie Antygony, przeł. M. Borowski, M. Sugiera, Kraków 2010.

${ }^{66}$ Koncepcję muzeum w Markowej jako urządzenia do pamiętania zaproponowała Maria Kobielska. Por. tejże, dz. cyt., s. 367-368. 
Cielecki M., Anna Bikont. Sendlerowa. W ukryciu, <https://instytutksiazki.pl/literatura,8,recenzje,25, wszystkie,0, sendlerowa-w-ukryciu,92.html> [dostęp: 7.06.2019].

Czaja M., Nowa humanistyka a performatywnośc literatury, <http://wakat.sdk.pl/nowa-humanistyka-a-performatywnosc-literatury/> [dostęp: 18.11.2019].

Czerwińska-Rydel A., Listy w butelce. Opowieść o Irenie Sendlerowej, Łódź 2018.

Derrida J., Sygnatura, zdarzenie, kontekst, [w:] tegoż, Pismo filozofii, przeł. B. Banasiak, Kraków 1993.

Fischer-Lichte E., Estetyka performatywności, przeł. M. Borowski, M. Sugiera, Kraków 2008. Forecki P., Po Jedwabnem. Anatomia pamięci funkcjonalnej, Warszawa 2018.

Grabowski A., Dramatu-pisanie jako performans. Zeznanie sprawcy, [w:] Performans, performatywność, performer. Próby definicji i analizy krytyczne, red. E. Bal, W. Świątkowska, Kraków 2013, s. 97-106.

Gross J.T., Sasiedzi. Historia zagłady żydowskiego miasteczka, Sejny 2000.

Grubowska H., Ta, która ratowała Żydów. Rzecz o Irenie Sendlerowej, Warszawa 2014. Jędrzejewski P., Brzydka próba uwiktania Ireny Sendlerowej. Szkoda, że Anna Bikont nie potrafita stanać ,,ponad”, <https://www.fronda.pl/a/jedrzejewski-brzydka-proba-uwiklania-ireny-sendlerowej-szkoda-ze-anna-bikont-nie-potrafila-stanac-ponad,101882.html> [dostęp: 7.06.2019].

Kącka K., Polityka historyczna: kreatorzy, narzędzia, mechanizmy dziatania, [w:] Narracje pamięci. Między polityka a historia, red. K. Kącka, J. Piechowiak-Lamparska, A. Ratke-Majewska, Torun 2015, s. 59-80.

Kobielska M., Polska pamięć autoafirmacyjna, „Teksty Drugie” 2016, nr 6, s. 358-374.

Kołodziej A., Mowa w (s)tarciu z pismem. Slam poetycki jako przykład symbiozy tekstu i wydarzania, [w:] Performans, performatywność, performer. Próby definicji i analizy krytyczne, red. E. Bal, W. Świątkowska, Kraków 2013, s. 89-96.

Krajewska A., Dramatyczna teoria literatury. Zarys problematyki, Poznań 2009.

Kubkowski P., „Dosyć nie umiem pisać” - Dzienniczek Faustyny Kowalskiej jako wydarzenie piśmienne i tekstowe, „Teksty Drugie” 2015, nr 4, s. 119-138.

Leociak J., Ratowanie. Opowieści Polaków i Żydów, Kraków 2010.

Łuczewski M., Kapitał moralny. Polityki historyczne w późnej nowoczesności, Kraków 2017.

Małochleb P., Strategia księowej, <http://malyformat.com/2018/06/strategia-ksiegowej/> [dostęp: 7.06.2019].

Mayer J., Życie w stoiku. Ocalenie Ireny Sendlerowej, przeł. R. Stiller, Warszawa 2013.

Mieszkowska A., Historia Ireny Sendlerowej, Warszawa 2018.

Mieszkowska A., Matka dzieci Holocaustu. Historia Ireny Sendlerowej, Warszawa 2004.

Mitosek Z., Mimesis krytyczna, „Pamiętnik Literacki” 1988, z. 3, s. 77-95.

Nijakowski L.M., Polska polityka pamięci. Esej socjologiczny, Warszawa 2008.

Nowak E., Kto uratował jedno życie. Historia Ireny Sendlerowej, Warszawa 2018.

Ostrowicka B., Irena Sendlerowa. Magiczny koralik, Warszawa 2018.

Sendlerowa I., Ci, którzy pomagali Żydom. (Wspomnienia z czasów okupacji hitlerowskiej), „Biuletyn Żydowskiego Instytutu Historycznego” 1963, nr 45-46, s. 234-247.

Sugiera M., Pytania o dramat, „Teksty Drugie” 2005, nr 1-2, s. 60-71.

Tokarska-Bakir J., Polska kolej podziemna - Sendlerowa dla dorostych, <http://wyborcza.

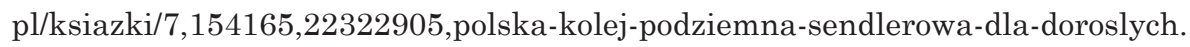
html> [dostęp: 7.06.2019]. 
Woźniak J., Performatyka wobec koncepcji dzieła w toku, [w:] Zwrot performatywny w kulturze. Szkice o obyczajach, literaturze, performansie i tańcu, red. M. Błaszczak, I. Górska, Poznań 2015, s. 15-35.

Żyrek-Horodyska E., Reportȧ் biograficzny czy biografia reportażowa? Refleksje genologiczne $i$ analiza przypadku, „Autobiografia” 2018, nr 2, s. 165-185. 